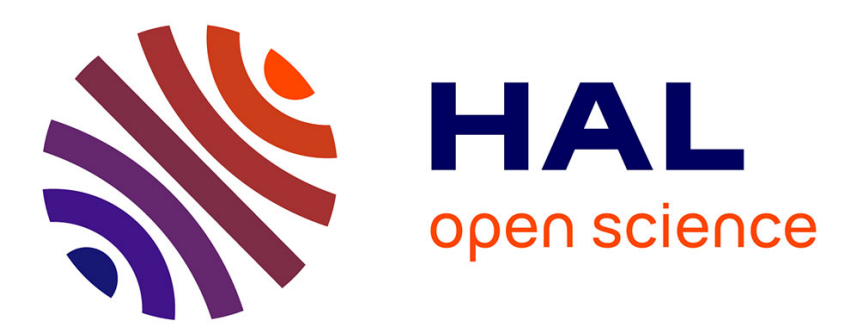

\title{
The multifaceted role of nerves in animal regeneration
}

Chiara Sinigaglia, Michalis Averof

\section{To cite this version:}

Chiara Sinigaglia, Michalis Averof. The multifaceted role of nerves in animal regeneration. Current Opinion in Genetics and Development, 2019, 57, pp.98-105. 10.1016/j.gde.2019.07.020 . hal02327714

\section{HAL Id: hal-02327714 \\ https://hal.science/hal-02327714}

Submitted on 22 Oct 2019

HAL is a multi-disciplinary open access archive for the deposit and dissemination of scientific research documents, whether they are published or not. The documents may come from teaching and research institutions in France or abroad, or from public or private research centers.
L'archive ouverte pluridisciplinaire HAL, est destinée au dépôt et à la diffusion de documents scientifiques de niveau recherche, publiés ou non, émanant des établissements d'enseignement et de recherche français ou étrangers, des laboratoires publics ou privés. 


\title{
The multifaceted role of nerves in animal regeneration
}

\author{
Chiara Sinigaglia and Michalis Averof
}

\begin{abstract}
Address: Institut de Génomique Fonctionnelle de Lyon (IGFL), Ecole Normale Supèrieure de Lyon and Centre National de la Recherche Scientifique (CNRS), 32 avenue Tony Garnier, 69007 Lyon, France

Corresponding author: Sinigaglia, Chiara (chi.sinigaglia@gmail.com)
\end{abstract}

The discovery that the nervous system plays a critical role in salamander limb regeneration, in 1823, provided the first mechanistic insights into regenerative phenomena and stimulated a long quest for molecular regulators. A role for nerves in the context of regeneration has been suggested for most vertebrate and invertebrate groups, thus offering a possible shared mechanism for the regulation of regenerative processes among animals. Methodological differences and technical limitations, especially in invertebrate groups, have so far hampered broad comparisons and the search for common principles on the role of nerves. This review considers both old and recent work in this topic and provides a broad perspective on the roles of nerves during regeneration. Nerves are found consistently to have important roles in regeneration, but their mode of action varies across species. The ongoing technological developments in a broad range of invertebrate models are now paving the way for the discovery of the shared and unique roles of nerves in animal regeneration. 


\section{Introduction}

The discovery that salamander limb regeneration depends on elements of the nervous system [1**] provided one of the first insights into the regulation of regenerative processes. Analogous influences of the nervous system were subsequently found in planarians, annelids, echinoderms, arthropods and many other animal groups, suggesting that nerve-dependency might represent a conserved feature of animal regeneration $[2,3]$.

Research on the topic has focused on vertebrates, particularly on amphibians, which have become the paradigm for understanding the mechanisms of nerve-dependent regeneration (extensively reviewed in Ref. [4]). In other animals, experimental approaches have been largely limited to surgical and pharmacological manipulations, to demonstrate the active role of nerves in regeneration. Technical limitations have hampered our understanding of molecular and cellular mechanisms that underpin this phenomenon in most animals, thus limiting cross-species comparisons and a broad evolutionary understanding $\left[5^{\star *}, 6^{\star}\right]$. Recent discoveries on the shared molecular mechanisms governing the development and physiology of nervous systems in animals (e.g. [7].), and the ongoing efforts to apply -omics, functional genetics and imaging approaches to a broader array of species [8] are now paving the way for re-addressing long-standing questions in this field.

\section{What is nerve-dependency?}

The term 'nerve-dependency' has been employed to refer to diverse phenomena. In its broadest sense, nerve-dependency would encompass any case where the presence of a nerve is needed for the correct unfolding of the regenerative process. The nerves could provide spatial or temporal signals. They could act directly, or indirectly through other cell types. Their effects could be all-ornone or graded, permissive or instructive.

There are three broad ways, in which the nervous system has been shown to contribute to regeneration (Figure 1):

a) Source of local signals: Nerve-dependency can be directly mediated through the local action of the nerve terminals, which release signaling molecules. In axolotl limbs, the growth factor FGF-2 produced by the nerve promotes the formation of the Apical Ectodermal Cap (AEC). The subsequent interactions between nerves and the AEC drive the regenerative process [9].

b) Support for other cell types: Nerves can also contribute by serving as a scaffold for other cell types with important roles, such as cells that provide essential signals or serve as progenitors during regeneration. These may be cells that are closely associated with nerves even in nonregenerative conditions, such as the Schwann cells and their precursors, which provide essential signals for regeneration in salamander limbs $\left[10^{* *}, 11\right]$ and in mouse digit tips $\left[5^{* *}\right]$, or mesenchymal progenitors that contribute to bone formation during digit tip regeneration $\left[12^{\star \star}\right]$. Equally, nerves can support other cell types that are not usually present in nerves but become transiently associated with them during regeneration. An example is the granule cell, a crinoidspecific cell type, which migrate along nerves and release essential growth factors [13]. Such transiently associated migratory cells also include progenitor cells, such as annelid neoblasts migrating along the ventral nerve cord to the wound site [14], or the scattered cells described in some sipunculid species, which leave the ventral nerve cord to generate epidermis and nervous system at the wound site [15]. 
c) Source of systemic signals: The nervous system may also perform systemic functions, essential for regenerative success - for example by releasing neurohormones in the circulatory system. This mode of action has been suggested for caudal regeneration of several annelid worms, which is impaired by brain ablation even in the presence of nerves at the wound site [16].

(a)

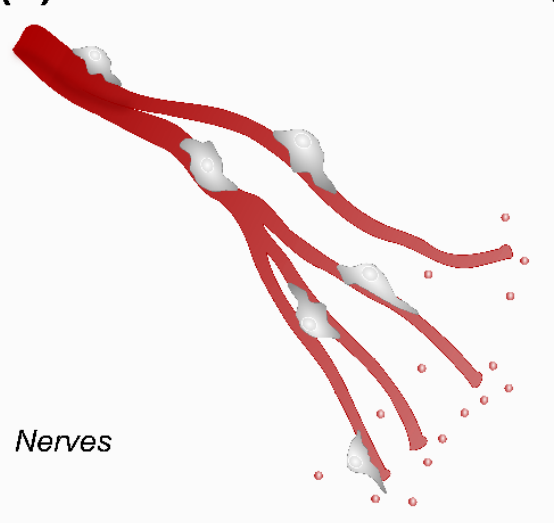

(b)

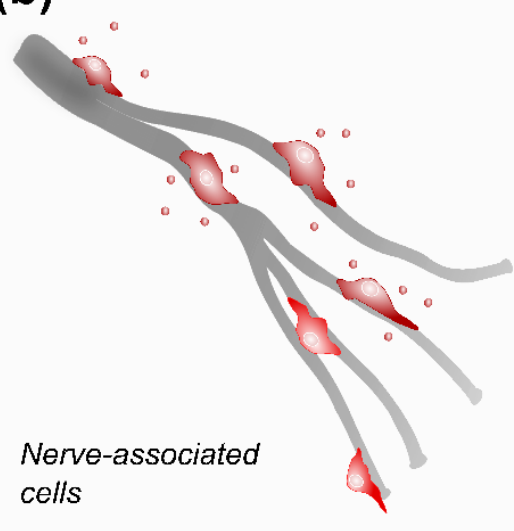

(c)

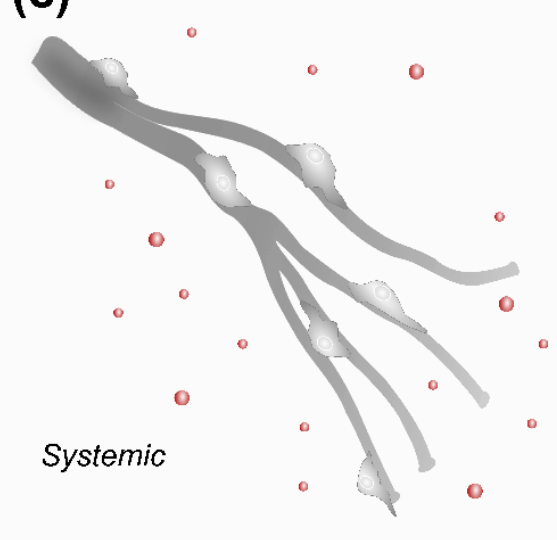

Figure 1: Modes of action of the nervous system during regeneration. The nervous system has been shown to contribute to regenerative processes in different ways, across animal groups. (a) Nerves can directly act as a source of local signals. (b) They can act as a support for other cell types, which provide signals and/or act as progenitors in the regenerating tissues. (c) Systemic signals originating from the central nervous system can also influence the regenerative process.

While nerves are not implicated in many aspects of embryonic development, they are known to play a role in specific cases. In development, as in regeneration, nerves can serve as a source of local instructive signals, a support or scaffold for other cell types, or a source of neuroendocrine signals that control development, metamorphosis and growth in a systemic fashion (e.g. [17]).

\section{Phylogenetic and methodological disparity}

Nearly two centuries of research on nerve-dependent regeneration produced a vast amount of disparate data, encompassing most animal groups (Figure 2, and Appendix). Vertebrate appendages (reviewed in Refs. [18,19]), echinoderm appendages (reviewed in Ref. [20]) and annelid bodies (reviewed in Ref. [21]) were extensively studied. Other taxa or regenerative processes received less attention, but nevertheless featured clear cases of nerve-dependent regeneration. For example, the presence of the nervous system was shown to be essential for body regeneration in a nemertean worm [22] and a holothurian [23]. 


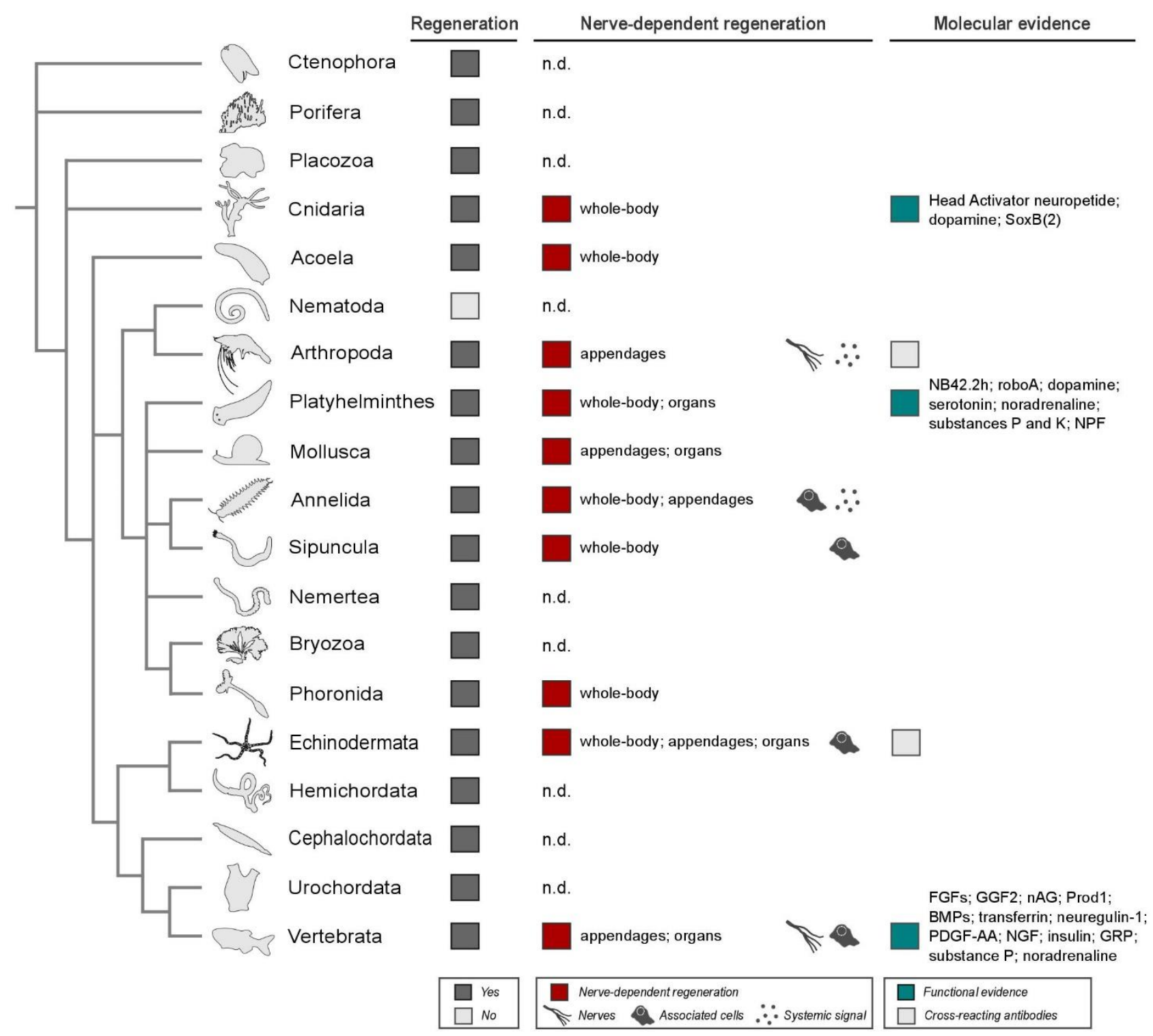

Figure 2: Distribution of nerve-dependent regeneration in animals. Most animal phyla include members with the ability to regenerate complex body parts (dark grey boxes). An influence of the nervous system during regeneration has been found in numerous instances (red boxes), while the molecular players involved in nerve-dependent regeneration (identified by pharmacological assays, immunological or genetic approaches) have been identified in some cases. Lack of evidence does not imply absence of nerve-dependent regeneration. n.d., not determined. Silhouettes adapted from PhyloPic.org, further information can be found in the Appendix.

The methodological approaches used to investigate the role of nerves have been very diverse, influenced by the history of technological developments and by the specific opportunities and constraints presented by each species. The purely surgical approaches employed in the early experiments, featuring burning needles to ablate the nervous system (e.g. classic study on a brittle star $\left[24^{\star}\right]$ ) or transplantation to re-combine regenerating tissues with nerves (as extensively applied to annelids, e.g. [25]), provided solid proof of the influence of the nervous system on regeneration, identifying nerve-dependent and nerve-independent phases $\left[26^{\star \star}\right]$. Later work focused on 'inducing' or 'trophic' factors mediating the effect of nerves. Biochemical analyses of body and nerve extracts identified candidate active substances, such as the organisines thought to be 
released by regenerating planarian brains [27], or the mitogenic glial growth factor detected in regenerating newt limbs [28]. Immunological and pharmacological experiments allowed to detect and to test the function of specific compounds, in vivo and on cell cultures, identifying for example the mitogenic function of transferrin in amphibian limb regeneration [29]. Gene-oriented approaches provided molecular insights into the interactions regulating nerve-dependency [30]. RNAi screens on planarians identified several genes that are expressed in the nervous system and promote regeneration, including $N B 42.2 h$ and $\operatorname{robo} A\left[31^{*}, 32\right]$. Differential expression analyses and a yeast-two hybrid screen allowed the identification of the Prod1 receptor and its ligand nAG, which mediate the interaction between Schwann cells and the AEC in regenerating salamander limbs $\left[10^{*}, 33\right]$.

\section{The multiple contributions of nerves}

Forgotten studies, incomplete knowledge, and diverse - sometimes outdated - technical approaches represent a challenge for a thorough re-evaluation of nerve dependency in regeneration, particularly when searching for shared regulators. A systematic comparison across species offers nevertheless an interesting perspective over their multiple roles. Nerves can play an essential role at different stages of regeneration - wound healing, cell proliferation, cell differentiation, patterning and morphogenesis.

Wound closure does not appear to depend strictly on the presence of nerves, but mounting evidence suggests that the nervous system could play a facilitating role in this process. Reepithelialization at the amputation plane in the absence of nerves has been reported for several species, including annelid worms [34], sea stars [35], zebrafish [36]. However, in several vertebrates, including mammals [37] and birds [38], denervation delays cutaneous wound healing. In amputated lobster limbs the migration of ectodermal cells appears more pronounced in regions that lie closer to nerves [39].

Severed nerves could facilitate wound healing by helping to detect injuries and to mount an immune response. Cut nerve terminals are among the first tissues to react after amputation, by retracting from the wound site and undergoing degeneration; examples are found in cephalopod molluscs [40], brittle stars [41], decapod crustaceans [42] and phoronids [43]. Injured nerves also stimulate macrophage recruitment $[44,45]$. Macrophages are necessary for cell proliferation at the amputation site; their depletion blocks regeneration in both salamander limbs [46] and zebrafish fins [47].

An increase of cell proliferation is a common regenerative response of most studied systems (reviewed in Ref. [48]). Proliferating cells may be broadly distributed (e.g. in asteroids), or localized close to the amputation plane, in a proliferating mass called blastema (e.g. in salamanders, planarians and crinoids) $[49,50]$.

Nervous systems have been shown to promote cell proliferation in numerous regenerating species, regardless of their regenerative strategies. Denervation experiments caused a reduction in the number of mitoses and prevented the formation of a histologically detectable blastema in regenerating newt limbs/tails [51], and in the ear of a regenerating mouse strain [52]. The molecular mediators of this function have been characterized in few vertebrate systems. In salamander limbs $\left[10^{*}\right]$ nerves play an essential role in triggering/sustaining cell proliferation in the blastema by secreting nAG. This protein binds to a receptor, Prod1, identified in responding blastemal cells, and elegant experiments have shown that the effects of limb denervation can be 
rescued by providing exogenous $\mathrm{nAG}$, even if nerve and muscle tissues could not regenerate normally $\left[10^{* *}\right]$. Cholinergic nerves promote cardiomyocyte proliferation during heart regeneration in both mouse and zebrafish [53].

In invertebrates, molecular evidence for a role of nerves in inducing cell proliferation is overall lacking. Some descriptive evidence would be consistent with such a role, such as the close proximity of nerves to proliferating cells (e.g. in crustaceans [42], enteropneusts [54], echinoderms [41], and annelids [55]) and the fact that cell proliferation starts concomitantly with the regrowth of nerves into the blastema (e.g. in cuttlefish [40]). Growth defects or delays in regeneration have been observed following denervation, particularly among regenerating arthropod limbs $\left[56^{*}, 57\right]$.

The influence of nerves on the differentiation of progenitor cells and on growth is even less well understood. In hydra, nerve cells secrete peptides controlling the spatial and temporal patterns of differentiation [58]. In the sea star, regeneration is entirely nerve-dependent, and denervation blocks the differentiation of progenitor cells, and the growth of the regenerating arm [35].

Innervation can also influence patterning and polarity. Clonal cell lineage tracing in mice revealed morphological defects in regenerating finger tips upon denervation, indicating that nerves affect tissue patterning in both ectodermal and mesodermal derivatives [59]. The nerve cord of annelids was shown to impart ventral identity to the regenerate (reviewed in Ref. [60]), while the central nervous system of planarians controls the polarity of regenerating body fragments by detecting the presence of cephalic structures [61]. Furthermore, the identity of regenerating elements might also depend on their nerve supply: in several crustaceans, the presence of the optic ganglion appears to be required for regenerating an eye and removal of that ganglion leads to regenerating an antenna-like structure [62].

Denervation commonly results in the formation of a stump that fails to regenerate, as classically shown after amputation of posterior body segments of annelids [63], echinoderm arms [24*], salamander limbs and fins of teleost fish [64]. In some instances, however, the removal of nerve induces a more dramatic response, where also tissues far from the wound degenerate. This phenomenon, observed initially in the denervated and amputated limbs of larval urodeles, has been termed the 'regression effect' $[65,66]$. In the denervated antennae of cockroaches, the amputated stump degenerated over several molts, but could regenerate once it was re-innervated $\left[67^{*}\right]$.

Re-routing nerves to a wounded area can also have a converse gain-of-function effect, inducing the ectopic formation of a regenerating structure. This effect has been best studied in axolotl limbs (termed the Accessory Limb Model, [68,69]), and also described during anterior regeneration in annelids [70].

\section{Searching for common molecular mediators}

The molecular regulation of nerve-dependent regeneration remains poorly understood, and most of the factors identified so far derive from vertebrate research (e.g. nAG and Prod1 [10**], FGFs [9,71], GGF2 [28], BMP [72], transferrin [29], and Neuregulin [6*] - reviewed in Refs. [19,21,73]).

Among the wide range of signaling molecules produced by nerves, neurotransmitters might represent the best candidates for conserved molecular mediators. Besides their well-known roles in neuronal communication, neurotransmitters have been implicated in development and shown to influence regeneration in several contexts [74]. In planarians dopamine levels vary significantly 
during regeneration, and treatment with a dopamine antagonist reduces cell proliferation, delaying regeneration $\left[7^{\star}\right]$. Analogous results have been obtained in the regenerating arms of sea star [76] and in regenerating fragments of a sea anemone [77]. Significant fluctuations in serotonin concentration during arm regeneration have been detected in crinoids [78]. Drug treatments have shown that serotonin promotes regeneration in planarians and that this role is counterbalanced by acetylcholine signaling [79]. Similarly, noradrenaline has been found to promote regeneration in planarians [75*] and annelids [80] and has been detected in the regenerating limbs of newt, where its levels correlate with cAMP activity [81].

Neuropeptides are signaling molecules that mediate local interactions between neurons or act systemically as hormones $[82,83]$. Substance P and substance $K$ (Neurokinin A), two neuropeptides of the tachykinin family, have been shown to have a pro-mitogenic effect on diverse tissues [84]. Treatment with substance $\mathrm{P}$ and $\mathrm{K}$ promotes neoblast proliferation in regenerating planarians [85]. Substance $P$ was also detected in the proliferating blastema of newt limbs, where it similarly stimulates regeneration [86]. Neuropeptide F (NPF) stimulates mitotic activity of neoblasts and promotes pharyngeal regeneration in planarians [87]. Interestingly, a pro-mitogenic action of NPF was recently shown in the germ stem cells niche of Drosophila [88]. Hydra polyps regeneration depends on the Head Activator $(\mathrm{HA})$ neuro-peptide, which promotes proliferation and differentiation of nerve and epithelial cells, via the cAMP pathway [58,89]. In mammals, HA promotes proliferation of nervous system or neuroendocrine-derived cells, during development [90]. Neuropeptides from cutaneous nerves contribute to wound healing in vertebrates: gastrinreleasing peptide (GRP, a homologue of amphibian bombesin) promotes wound healing in mammals by stimulating growth and spreading of keratinocytes [91].

\section{Nerve-dependency and the evolution of animal regeneration}

A widespread requirement for the presence of nerves emerges from the comparison of animal regenerative processes, suggesting that the nervous system could play a conserved role. Given the ongoing efforts to identify any unifying principles in the unevenly distributed regenerative capacities of animals, finding a shared role for the nervous system would have profound consequences for our understanding of the evolution of regenerative properties [ $\left.92^{* *}\right]$.

The evidence reviewed here, however, highlights the diversity of the various processes classified as 'nerve- dependent regeneration'. The function of nerves can be mediated locally by the axons themselves, by cells variably associated with the nervous system, or systemically by circulating signals. Nerves can intervene at different stages of the regenerative process, with the control of proliferation being perhaps the most broadly shared feature. At present, it is uncertain which aspects could be considered homologous and compared across widely divergent groups, in terms of the mode of action, the cell types involved or the molecular mediators. Within vertebrates, the scaffolding/support that nerves provide for factor-secreting glial cells could be considered as a shared feature, but the molecular regulators only partially overlap between salamander limbs (the

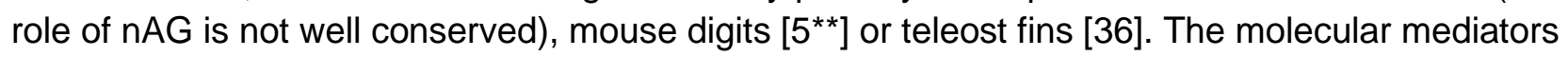
might evolve rapidly, even if the overall process is conserved.

The lack of comparable molecular data across animals represents an important obstacle for the emergence of a unified view. Cephalopod molluscs, despite their excellent regenerative abilities [93] and the extensive knowledge about the physiology of their nervous systems [94], appear to have been largely overlooked with regard to nerve- dependent regeneration. Similarly, no relevant molecular data are available for cephalochordates or ctenophores, two groups with high 
regenerative capabilities and relevant phylogenetic positions $[95,96]$. The discovery of neuropeptide signaling in placozoans, a non-bilaterian group lacking a nervous system [82,97], opens the intriguing possibility that neuropeptides might be involved in regeneration even in the absence of a nervous system.

Tools are now becoming available to tackle the evolution of nerve dependent regeneration through a broader sampling of animal groups. Achieving denervation by means of precise laser ablation or inducible genetic cell ablation systems, instead of invasive surgery, now allow to spatially and temporally control the interactions between nerves and target cells. Transgenic reporters and in vivo cell tracking approaches provide more powerful/specific ways to assess the effects that denervation has on regeneration, for example by uncoupling the dynamics of axons and nerveassociated cells. These approaches could be applicable and particularly informative in arthropods, where parallels with vertebrate regeneration such as the role of satellite-like cells in regenerating muscles have already been established [98]. Classical ablation studies in cockroaches and crustaceans have thus far only revealed subtle effects of removing nerves during regeneration, possibly due to the fast regrowth of axons into the stump [99]. In vivo imaging of regeneration using transgenic reporters, in the crustacean Parhyale [100], would allow to effectively monitor the denervation process and to dissect the cellular events that follow.

Nerve-dependent regeneration is a complex process and understanding its evolution will be challenging. The phenomenon is so widespread that it could be ancestral, despite the high variability observed between and within animal groups. Alternatively, there may be no unifying principle; nerves may have been co-opted into the regenerative process multiple times with different roles. Investigating the evolution of nerve-dependent regeneration with a common approach in a broader sample of animals will allow for a better understanding of the evolution of regenerative developmental mechanisms.

\section{Conflicts of interest statement}

Nothing declared.

\section{Acknowledgements}

We thank Igor Adameyko for comments on the manuscript. Our work is supported by the European Research Council, under the European Union Horizon 2020 program, grant ERC-2015-AdG \#694918. We apologize to all the authors whose work could not be cited due to space limitations.

\section{References and recommended reading}

Papers of particular interest, published within the period of review, have been highlighted as: * of special interest, ${ }^{* *}$ of outstanding interest

1. ${ }^{* *}$ Todd TJ: On the process of reproduction of the members of the aquatic salamander. Quart $\mathrm{J}$ Sci Arts Lib 1823, 16:84-86. 
This seminal study opened the field of nerve-dependent regeneration research, even before the development of a cell theory. Todd studied regeneration - termed 'reproduction' - of salamander limbs and tails, and demonstrated the influences of innervation on the process. He correctly identified the critical windows of sensitivity by performing denervation experiments at different stages of regeneration.

2. Dinsmore CE: A History of Regeneration Research. Milestones in the Evolution of a Science. Cambridge University Press; 1991.

3. Farkas JE, Monaghan JR: A brief history of the study of nerve dependent regeneration. Neurogenesis 2017, 4:e1302216.

4. Kumar A, Brockes JP: Nerve dependence in tissue, organ, and appendage regeneration. Trends Neurosci 2012, 35:691-699.

5. ** Johnston AP, Yuzwa SA, Carr MJ, Mahmud N, Storer MA, Krause MP, Jones K, Paul S, Kaplan DR, Miller FD: Dedifferentiated Schwann cell precursors secreting paracrine factors are required for regeneration of the mammalian digit tip. Cell Stem Cell 2016, 19:433-448.

The authors identified a role for nerve-associated Schwann cell precursors (SCPs) in the regeneration of mouse digit tips, thus showing that glial cells are also required for regeneration in mammals. SCPs dedifferentiate and secrete oncostatin $\mathrm{M}$ and platelet-derived growth factor $\mathrm{AA}$, which promote blastema growth and can rescue defects of denervated digits. Perturbation of SCPs signaling causes morphogenesis defects, in both mesodermal and ectodermal derivatives.

6. * Farkas JE, Freitas PD, Bryant DM, Whited JL, Monaghan JR: Neuregulin-1 signaling is essential for nerve-dependent axolotl limb regeneration. Development 2016, 143:2724-2731.

This study identified nerve secreted Neuregulin-1 (NRG1) as an essential mediator of the interaction between nerves and Schwann cells during regeneration in axolotl. NRG1 localizes to the wound epithelium before blastema formation, and is later expressed in proliferating blastemal cells, together with its receptor ErbB2. Perturbation of NRG1 suppresses regeneration, while additional expression rescues denervated limbs.

7. Kelava I, Rentzsch F, Technau U: Evolution of eumetazoan nervous systems: insights from cnidarians. Philos Trans R Soc B Biol Sci 2015, 370:20150065.

8. Mokalled MH, Poss KD: A regeneration toolkit. Dev Cell 2018, 47:267-280.

9. Mullen LM, Bryant SV, Torok MA, Blumberg B, Gardiner DM: Nerve dependency of regeneration: the role of distal-less and FGF signaling in amphibian limb regeneration. Development 1996, 122:3487-3497.

10. ${ }^{* *}$ Kumar A, Godwin JW, Gates PB, Garza-Garcia AA, Brockes JP: Molecular basis for the nerve dependence of limb regeneration in an adult vertebrate. Science 2007, 318:772-777.

This study identified nAG, a protein secreted by Schwann cell, which controls proliferation of blastema cells during newt limb regeneration. A yeast-two-hybrid screen identified nAG as the ligand for the surface receptor Prod1, expressed by blastema cells. Electroporation of nAG into denervated blastemas could rescue regeneration.

11. Kumar A, Delgado JP, Gates PB, Neville G, Forge A, Brockes JP: The aneurogenic limb identifies developmental cell interactions underlying vertebrate limb regeneration. Proc Natl Acad Sci U S A 2011, 108:13588-13593. 
12. ** Carr MJ, Toma JS, Johnston AP, Steadman PE, Yuzwa SA, Mahmud N, Frankland PW, Kaplan DR, Miller FD: Mesenchymal precursor cells in adult nerves contribute to mammalian tissue repair and regeneration. Cell Stem Cell 2019, 24:240-256.

Using a combination of single-cell RNA sequencing and lineage tracing, the authors demonstrated that peripheral nerves constitute a reservoir of mesenchymal precursor cells directly contributing to digit regeneration and skin repair in mouse.

13. Candia Carnevali MD, Bonasoro F: Mechanisms of arm regeneration in Antedon mediterranea (Echinodermata, Crinoidea). Anim Biol 1994, 3:83-88.

14. Zhinkin L: The influence of the nervous system on regeneration in Rhynchelmis limosella hof. $J$ Exp Zool 1936, 73:43-65.

15. Storch V, Moritz K: Uber die Regeneration des Integumentes aus Zellen im Ventralnervenstrang von Phascolion strombi (Montagu) (Sipunculida). Zeitschrift fur Zellforsch und Mikroskopische Anat 1970, 110:258-267.

16. Boilly B: Mode d'action du cerveau sur la régénération caudale de Nereis diversicolor O.F. Muller (Annèlide Polychéte). Wilhelm Roux Arch Entwickl Mech Org 1974, 174:195-209.

17. Knox SM, Lombaert IMA, Reed X, Vitale-Cross L, Gutkind JS, Hoffman MP: Parasympathetic innervation maintains epithelial progenitor cells during salivary organogenesis. Science 2010 , 329:1645-1647.

18. Stocum DL: Nerves and proliferation of progenitor cells in limb regeneration. Dev Neurobiol 2018, 0-2.

19. Pirotte N, Leynen N, Artois T, Smeets K: Do you have the nerves to regenerate? The importance of neural signalling in the regeneration process. Dev Biol 2016, 409:4-15.

20. Carnevali C: Regeneration in echinoderms: repair, regrowth, cloning. ISJ 2006, 3:64-76.

21. Boilly B, Boilly-Marer Y, Bely AE: Regulation of dorso-ventral polarity by the nerve cord during annelid regeneration: a review of experimental evidence. Regeneration (Oxford, England) 2017, 4:54-68.

22. Coe WR: Regeneration in nemerteans. II. Regeneration of small sections of the body split or partially split longitudinally. J Exp Zool 1930, 57:109-144.

23. Smith GN: Regeneration in the sea cucumber Leptosynapta. II. The regenerative capacity. J Exp Zool 1971, 177:331-342.

24. * Morgulis S: Regeneration in the brittle-star Ophiocoma pumila, with reference to the influence of the nervous system. Proc Am Acad Arts Sci 1909, 44:655.

Morgulis first demonstrated the role played by nerves in the regenerating arms of ophiuroids. This work elegantly proved the necessity of an intact nerve.

25. Sayles LP: Implants consisting of young buds, formed in anterior regeneration in Clymenella, plus the nerve cord of the adjacent old part. J Exp Zool 1943, 94:145-159.

26. ${ }^{* *}$ Schotté OE, Butler EG: Phases in regeneration of the urodele limb and their dependence upon the nervous system. J Exp Zool 1944, 97:95-121. 
The authors demonstrated that nerves are necessary for the setting up and maintenance of the blastema in axolotl, but are not required after the beginning of the morphogenetic phase.

27. Lender T: Recherches expérimentales sur la nature et les propriété s de l'inducteur de la régénération des yeux de la planaire Polycelis nigra. Development 1956, 4:196-216.

28. Brockes JP, Kintner CR: Glial growth factor and nerve-dependent proliferation in the regeneration blastema of urodele amphibians. Cell 1986, 45:301-306.

29. Mescher AL, Connell E, Hsu C, Patel C, Overton B: Transferrin is necessary and sufficient for the neural effect on growth in amphibian limb regeneration blastemas. Dev Growth Differ 1997, 39:677-684.

30. Monaghan JR, Epp LG, Putta S, Page RB, Walker JA, Beachy CK, Zhu W, Pao GM, Verma IM, Hunter T, Bryant SV: Microarray and cDNA sequence analysis of transcription during nervedependent limb regeneration. BMC Biol 2009, 7 p.1.

31. * Cebrià F, Newmark PA: Morphogenesis defects are associated with abnormal nervous system regeneration following roboA RNAi in planarians. Development 2007, 134:833-837.

This study provided early molecular genetic evidence of nerve-dependency among invertebrates. It showed that defective nervous system in the planaria Schmidtea mediterranea impairs pattern formation during regeneration, leading to the development of ectopic structures. The nervous system was perturbed by RNAi knockdown of the axon-guidance molecule roundabout (Smed-roboA).

32. Reddien PW, Bermange AL, Murfitt KJ, Jennings JR, Sànchez Alvarado A: Identification of genes needed for regeneration, stem cell function, and tissue homeostasis by systematic gene perturbation in planaria. Dev Cell 2005, 8:635-649.

33. da Silva SM, Gates PB, Brockes JP: The newt ortholog of CD59 is implicated in proximodistal identity during amphibian limb regeneration. Dev Cell 2002, 3:547-555.

34. Bouc-Lassalle AM: La cicatrisation des plaies de la paroi du corps chez le Lumbricien Eisenia foetida Sav., en présence et en l'absence d'innervation. C. r. hebd. Seanc Acad Sci Paris 1968, 267:2167-2169.

35. Huet M: Role of nervous-system during regeneration of arm in Asterina gibbosa penn (Echinoderma, Asteridae). J Embryol Exp Morphol 1975, 33:535-552.

36. Simòes MG, Bensimon-Brito A, Fonseca M, Farinho A, Valério F, Sousa S, Afonso N, Kumar A, Jacinto A: Denervation impairs regeneration of amputated zebrafish fins. BMC Dev Biol 2014, $14: 49$.

37. Ashrafi M, Baguneid M, Bayat A: The role of neuromediators and innervation in cutaneous wound healing. Acta Derm Venereol 2016, 96:587-597.

38. Harsum S, Clarke JDW, Martin P: A reciprocal relationship between cutaneous nerves and repairing skin wounds in the developing chick embryo. Dev Biol 2001, 238:27-39.

39. Emmel VE: A study of the differentiation of tissues in the regenerating crustacean limb. Am J Anat 1910, 10:109-158. 
40. Féral J-P: La régénération des bras de la Seiche Sepia officinalis L. (Cephalopoda, Sepioidea) II. - Etude histologique et cytologique. Cah Biol Mar 1979, 20:29-42.

41. Biressi ACM, Zou T, Dupont S, Dahlberg C, Di Benedetto C, Bonasoro F, Thorndyke M, Carnevali MDC: Wound healing and arm regeneration in Ophioderma longicaudum and Amphiura filiformis (Ophiuroidea, Echinodermata): comparative morphogenesis and histogenesis.

Zoomorphology 2010, 129:1-19.

42. Paul JH: Regeneration of the legs of decapod crustacea from the preformed breaking plane. Proc R Soc Edinburgh 1915, 35:78-94.

43. Emig CC: L'histogenése régénératrice chez les Phoronidiens. Dev Genes Evol 1973, 173:235248.

44. Rosenberg AF, Wolman MA, Franzini-Armstrong C, Granato M: In vivo nerve-macrophage interactions following peripheral nerve injury. J Neurosci 2012, 32:3898-3909.

45. Tsai SL, Baselga-Garriga C, Melton DA: Blastemal progenitors modulate immune signaling during early limb regeneration. Development 2019, 146 dev169128.

46. Godwin JW, Pinto AR, Rosenthal NA: Macrophages are required for adult salamander limb regeneration. Proc Natl Acad Sci U S A 2013, 110:9415-9420.

47. Petrie TA, Strand NS, Tsung-Yang C, Rabinowitz JS, Moon RT: Macrophages modulate adult zebrafish tail fin regeneration. Development 2014, 141:2581-2591.

48. Ricci L, Srivastava M: Wound-induced cell proliferation during animal regeneration. Wiley Interdiscip Rev Dev Biol 2018, 7:e321.

49. Candia Carnevali MD: Regeneration in echinoderms: repair, regrowth, cloning. Invertebr Surviv J 2006:64-76.

50. Alvarado AS, Tsonis PA: Bridging the regeneration gap: genetic insights from diverse animal models. Nat Rev Genet 2006, 7:873-884.

51. Schotté OE, Liversage RA: Effects of denervation and amputation upon the initiation of regeneration in regenerates of Triturus. J Morphol 1959, 105:495-527.

52. Buckley G, Wong J, Metcalfe AD, Ferguson MWJ: Denervation affects regenerative responses in MRL/MpJ and repair in C57BL/6 ear wounds. J Anat 2012, 220:3-12.

53. Mahmoud Al, O'Meara CC, Gemberling M, Zhao L, Bryant DM, Zheng R, Gannon JB, Cai L, Choi WY, Egnaczyk GF, Burns CE: Nerves regulate cardiomyocyte proliferation and heart regeneration. Dev Cell 2015, 34:387-399.

54. Rychel AL, Swalla BJ: Anterior regeneration in the hemichordate Ptychodera flava. Dev Dyn 2008, 237:3222-3232.

55. Coulon J, Thouveny Y: Relation entre l'innervation et l'activité prolifératrice des cellules blastematique au cours de la régénération de l'annélide polychete Owenia fusiformis: études ultrastructurale et autoradiographique. Arch Anat Microsc Morphol Exp 1984, 73:45-56.

56. * Nüesch $\mathrm{H}$ : The role of the nervous system in insect morphogenesis and regeneration. Ann Rev Entomol 1968, 13:27-44. 
Extensive analysis of the literature on the roles played by nerves during developmental processes in insects.

57. Needham AE: The central nervous system and regeneration in Crustacea. J Exp Biol 1953, 30:151-159.

58. Schaller HC, Hermans-Borgmeyer I, Hoffmeister SA: Neuronal control of development in hydra. Int J Dev Biol 1996, 40:339-344.

59. Rinkevich Y, Montoro DT, Muhonen E, Walmsley GG, Lo D, Hasegawa M, Januszyk M, Connolly AJ, Weissman IL, Longaker MT: Clonal analysis reveals nerve-dependent and independent roles on mammalian hind limb tissue maintenance and regeneration. Proc Natl Acad Sci U S A 2014, 111:9846-9851.

60. Oviedo NJ, Morokuma J, Walentek P, Kema IP, Gu MB, Ahn JM, Hwang JS, Gojobori T, Levin M: Long-range neural and gap junction protein-mediated cues control polarity during planarian regeneration. Dev Biol 2010, 339:188-199.

61. Herbst C: Über die Regeneration von antennenähnlichen Organen an Stelle von Augen. Arch für Entwicklungsmechanik der Org 1910, 30:1-14.

62. Bailey PL: The influence of the nervous system in the regeneration of Eisenia foetida savigny. $\mathrm{J}$ Exp Zool 1930, 57:473-509.

63. Géraudie J, Singer M: Nerve dependent macromolecular synthesis in the pectoral fin regenerate of the fish, Fundulus. J Exp Zool 1979, 208:281-286.

64. Schotté OE, Butler EG: Morphological effects of denervation and amputation of limbs in urodele larvae. J Exp Zool 1941, 87:279-322.

65. Karczmar AG: The role of amputation and nerve resection in the regressing limbs of urodele larvae. J Exp Zool 1946, 103:401-427.

66. Drescher W: Regenerationsversuche am gehirn von Periplaneta Americana unter berucksichtigung von verhaltensunderung und neurosekretion. Zeitschrift fur Morphol und Okol der Tiere 1960, 48:576-649.

67. * Satoh A, Gardiner DM, Bryant SV, Endo T: Nerve-induced ectopic limb blastemas in the axolotl are equivalent to amputation-induced blastemas. Dev Biol 2007, 312:231-244.

The Accessory Limb Model (ALM) demonstrates the inducing role of nerves and their essential interaction with the wound epithelium. Re-routing nerves to a lateral wound in an axolotl limb, induces a blastema-like mass of undifferentiated cells; if a skin fragment is grafted to the wound, the ectopic blastema will progress and generate a supernumerary limb. Otherwise the blastema-like structure will regress. This paper builds on previous work on ALM, provides a systematic analysis of tissue dynamics.

68. Ruben LN: Delayed denervation and accessory limb formation in urodeles. Nature 1959, 183:765-766.

69. Bely AE: Early events in annelid regeneration: a cellular perspective. Integr Comp Biol 2014, 54:688-699.

70. Nacu E, Gromberg E, Oliveira CR, Drechsel D, Tanaka EM: FGF8 and SHH substitute for anterior-posterior tissue interactions to induce limb regeneration. Nature 2016, 533:407-410. 
71. Makanae A, Mitogawa K, Satoh A: Co-operative Bmp- and Fgf-signaling inputs convert skin wound healing to limb formation in urodele amphibians. Dev Biol 2014, 396:57-66.

72. Boilly B, Faulkner S, Jobling P, Hondermarck H: Nerve dependence: from regeneration to cancer. Cancer Cell 2017, 31:342-354.

73. Satoh A, Mitogawa K, Makanae A: Nerve roles in blastema induction and pattern formation in limb regeneration. Int J Dev Biol 2018, 62:605-612.

74. Lauder JM: Neurotransmitters as morphogens. Prog Brain Res 1988, 73:365-387.

75. * Franquinet PR: Rôle de la sérotonine et des catécholamines dans la régénération de la planaire Polycelis tenuis. Development 1979, 51:85.

This work represents an example of the type of studies performed in the ' 70 s and the 80 ' to understand the effect of neurotransmitters on regeneration. Planarians were treated with different combinations of active peptides and antagonists, whose effects were evaluated by histological and morphological analysis. This study showed that serotonin and dopamine promote regeneration.

76. Huet M, Franquinet R: Histofluorescence study and biochemical assay of catecholamines (Dopamine and Noradrenaline) during the course of arm-tip regeneration in the starfish, Asterina gibbosa (Echinodermata, Asteroidea). Histochemistry 1981, 72:149-154.

77. Lenicque PM, Féral J-P: Effects of biogenic amines on the regeneration of small pieces of the pedal disc of the sea anemone Metridium senile (linnaeus). Comp Biochem Physiol Part C Comp Pharmacol 1977, 57:91-93.

78. Sugni M, Wilkie IC, Burighel P, Carnevali MDC: New evidence of serotonin involvement in the neurohumoral control of crinoid arm regeneration: effects of parachlorophenylanine and methiothepin. J Mar Biol Assoc U K 2010, 90:555.

79. Lenicque PM, Fe' ral JP: A mechanism of action of neurotransmitters on the regeneration of the planarian worm Dugesia tigrina. Role of acetylcholine as a negative feed-back. Acta Zool 1976, 57:1-5.

80. Chapron C: Etude comparée de la nature et du mode d'action des substances neurotrophiques intervenant dans la régénération des oligochétes et des amphibiens. C R Acad Sci Paris 1973, 276:1463-1466.

81. Taban C, Cathieni M, Schorderet M: Cyclic AMP and noradrenaline sensitivity fluctuations in regenerating newt tissue. Nature 1978, 271:470-472.

82. Elphick MR, Mirabeau O, Larhammar D: Evolution of neuropeptide signalling systems. J Exp Biol 2018, 221: jeb151092.

83. Jékely G, Melzer S, Beets I, Grunwald Kadow IC, Koene J, Haddad S, Holden-Dye L: The long and the short of it - a perspective on peptidergic regulation of circuits and behaviour. J Exp Biol 2018, 221 :jeb166710.

84. Zachary I, Woll PJ, Rozengurt E: A role for neuropeptides in the control of cell proliferation. Dev Biol 1987, 124:295-308.

85. Baguna J, Salò E, Romero R: Effects of activators and antagonists of the neuropeptides substance $\mathrm{P}$ and substance K on cell proliferation in planarians. Int J Dev Biol 1989, 33:261-266. 
86. Smith MJ, Globus M, Vethamany-Globus S: Nerve extracts and substance P activate the phosphatidylinositol signaling pathway and mitogenesis in newt forelimb regenerates. Dev Biol 1995, 167:239-251.

87. Kreshchenko N: Functions of flatworm neuropeptides NPF, GYIRF and FMRF in course of pharyngeal regeneration of anterior body fragments of planarian, Girardia tigrina. Acta Biol Hung 2008, 59:199-207.

88. Ameku T, Yoshinari Y, Texada MJ, Kondo S, Amezawa K, Yoshizaki G, Shimada-Niwa Y, Niwa $\mathrm{R}$ : Midgut-derived neuropeptide $\mathrm{F}$ controls germline stem cell proliferation in a mating-dependent manner. PLoS Biol 2018, 16:e2005004.

89. Schaller HC, Bodenmüller $\mathrm{H}$ : Isolation and amino acid sequence of a morphogenetic peptide from hydra. Proc Natl Acad Sci U S A 1981, 78:7000-7004.

90. Rezgaoui M, Süsens U, Ignatov A, Gelderblom M, Glassmeier G, Frankel, Urny J, Imai Y, Takahashi $\mathrm{R}$, Chica Schaller $\mathrm{H}$ : The neuropeptide head activator is a high-affinity ligand for the orphan G-protein-coupled receptor GPR37. J Cell Sci 2006, 119:542-549.

91. Baroni A, Perfetto B, Canozo N, Braca A, Farina E, Melito A, De Maria S, Carteni M: Bombesin: a possible role in wound repair. Peptides 2008, 29:1157-1166.

92. ${ }^{* *}$ Bely AE, Nyberg KG: Evolution of animal regeneration: re-emergence of a field. Trends Ecol Evol 2010, 25:161-170.

An overview of the diversity of regenerating processes, including the phylogenetic distribution of regeneration, and the reasons behind the loss of regenerative capacities in certain groups.

93. Imperadore P, Fiorito G: Cephalopod tissue regeneration: consolidating over a century of knowledge. Front Physiol 2018, 9:593.

94. Katz PS: Phylogenetic plasticity in the evolution of molluscan neural circuits. Curr Opin Neurobiol 2016, 41:8-16.

95. Somorjai IML, Somorjai RL, Garcia-Fernàndez J, Escrivà H: Vertebrate-like regeneration in the invertebrate chordate amphioxus. Proc Natl Acad Sci U S A 2012, 109:517-522.

96. Martindale MQ: The onset of regenerative properties in ctenophores. Curr Opin Genet Dev 2016, 40:113-119.

97. Varoqueaux F, Williams EA, Grandemange S, Truscello L, Kamm K, Schierwater B, Jekely G, Fasshauer D: High cell diversity and complex peptidergic signaling underlie placozoan behavior. Curr Biol 2018, 28:3495-3501.

98. Konstantinides N, Averof M: A common cellular basis for muscle regeneration in arthropods and vertebrates. Science 2014, 343:788-791.

99. Bodenstein D: Contributions to the problem of regeneration in insects. J Exp Zool 1955, 129:209-224.

100. Alwes F, Enjolras C, Averof M: Live imaging reveals the progenitors and cell dynamics of limb regeneration. eLife 2016, 5:1-18. 


\section{Appendix}

\section{Supplementary Table. References related to Figure 2.}

\begin{tabular}{|c|c|c|}
\hline \multicolumn{3}{|c|}{ Nerve-dependent regeneration } \\
\hline & $\begin{array}{l}\text { References in } \\
\text { main text }\end{array}$ & Further references \\
\hline Ctenophora & 96 & \\
\hline Porifera & & $\begin{array}{l}\text { 1. Wilson, H. V. On some phenomena of coalescence and regeneration in sponges. J. Exp. Zool. 5, 245- } \\
258 \text { (1907). }\end{array}$ \\
\hline Placozoa & 97 & \\
\hline Cnidaria & $58,77,89,90$ & 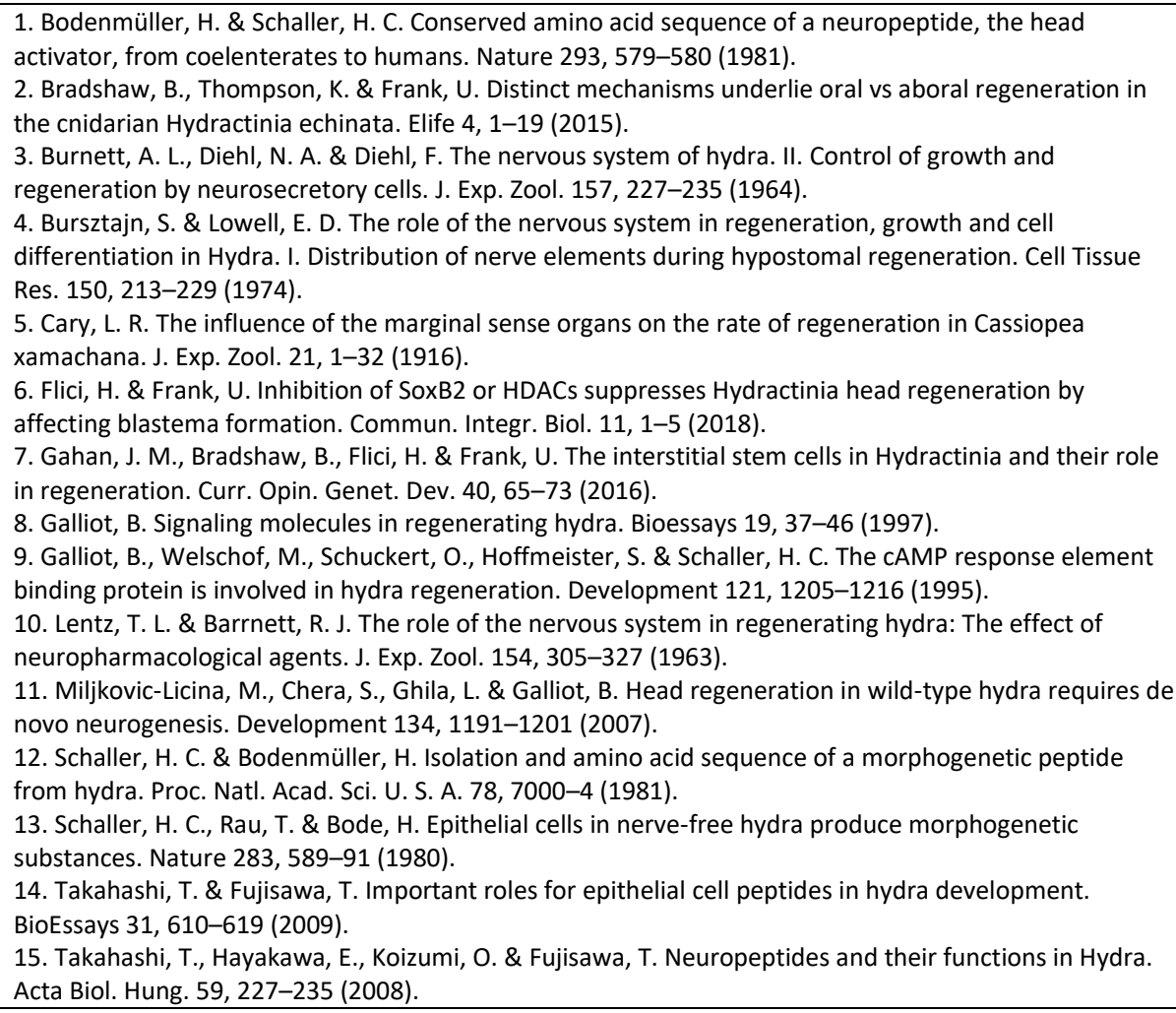 \\
\hline Acoela & & $\begin{array}{l}\text { 1. Bery, A. \& Martínez, P. Acetylcholinesterase activity in the developing and regenerating nervous } \\
\text { system of the acoel Symsagittifera roscoffensis. Acta Zool. 92, 383-392 (2011). } \\
\text { 2. Dittmann, I. L., Zauchner, T., Nevard, L. M., Telford, M. J. \& Egger, B. SALMFamide2 and serotonin } \\
\text { immunoreactivity in the nervous system of some acoels (Xenacoelomorpha). J. Morphol. 279, 589-597 } \\
\text { (2018). } \\
\text { 3. Gaerber, C. W., Salvenmoser, W., Rieger, R. M. \& Gschwentner, R. The nervous system of } \\
\text { Convolutriloba (Acoela) and its patterning during regeneration after asexual reproduction. } \\
\text { Zoomorphology 126, 73-87 (2007). } \\
\text { 4. Sprecher, S.G., Bernardo-Garcia, F.J., van Giesen, L., Hartenstein, V., Reichert, H., Neves, R., Bailly, X., } \\
\text { Martinez, P. and Brauchle, M. Functional brain regeneration in the acoel worm Symsagittifera } \\
\text { roscoffensis. Biol. Open 4, 1688-1695 (2015). }\end{array}$ \\
\hline Arthropoda & $\begin{array}{l}39,42,56,57 \\
61,66,98-100\end{array}$ & $\begin{array}{l}\text { 1. Bazin, F. La régénération de la patte chez le crabe Carcinus maenas (L.). (Thesis, Universitè de Caen, } \\
\text { 1984). } \\
\text { 2. Bohn, H. Growth-promoting effect of haemocytes on insect epidermis in vitro. J. Insect Physiol. 21, } \\
\text { 1283-1293 (1975). } \\
\text { 3. Bullière, P. D. Sur le déterminisme de la qualité régionale des régénérats d'appendices chez la Blatte, } \\
\text { Blabera craniifer. Development 23, (1970). } \\
\text { 4. Das, S. Morphological, molecular, and hormonal basis of limb regeneration across pancrustacea. } \\
\text { Integr. Comp. Biol. 55, 869-877 (2015). } \\
\text { 5. Fredericq, L. Nouvelles recherches sur l'autotomie chez la crabe. Bull. l'Académie R. des Sci. des }\end{array}$ \\
\hline
\end{tabular}




\begin{tabular}{|c|c|c|}
\hline & & $\begin{array}{l}\text { Lettres des B. art. Belgique. Sci. XLVI (1891). } \\
\text { 6. Herbst, C. Über die Regeneration von antennenähnlichen Organen an Stelle von Augen. Arch. für } \\
\text { Entwicklungsmechanik der Org. 2, 544-558 (1896). } \\
\text { 7. Herbst, C. Über die Regeneration von antennenähnlichen Organen an Stelle von Augen. Arch. für } \\
\text { Entwickelungsmechanik der Org. 9, 215-292 (1899). } \\
\text { 8. Herbst, C. Über die Regeneration von antennenähnlichen Organen an Stelle von Augen. Arch. für } \\
\text { Entwicklungsmechanik der Org. 13, 407-489 (1901). } \\
\text { 9. Hopkins, P. M. Limb regeneration in the fiddler crab, Uca pugilator: hormonal and growth factor } \\
\text { control. Am. Zool. 41, 389-398 (2001). } \\
\text { 10. Hopkins, P. M., Chung, A. C.-K. \& Durica, D. S. Limb regeneration in the fiddler crab, Uca pugilator: } \\
\text { histological, physiological and molecular considerations. Am. Zool. 39, 513-526 (1999). } \\
\text { 11. Khan, S. J., Schuster, K. J. \& Smith-Bolton, R. K. Regeneration in Crustaceans and Insects. eLS (2001). } \\
\text { 12. Kopeć, S. The influence of the nervous system on the development and regeneration of muscles and } \\
\text { integument in insects. J. Exp. Zool. 37, 14-25 (1923). } \\
\text { 13. Maruzzo, D. \& Bortolin, F. Arthropod regeneration. Arthropod Biology and Evolution: Molecules, } \\
\text { Development, Morphology (2013). } \\
\text { 14. Mellon, D. \& Stephens, P. J. Limb morphology and function are transformed by contralateral nerve } \\
\text { section in snapping shrimps. Nature 272, } 246-248 \text { (1978). } \\
\text { 15. Needham, A. E. Depletion and recuperation of the local factors during repeated regeneration. J. Exp. } \\
\text { Zool. 112, 207-231 (1949). } \\
\text { 16. Needham, A. E. Peripheral nerve and regeneration in Crustacea. J. Exp. Biol. 22, 107-9 (1945). } \\
\text { 17. Ost, J. Zur Kenntnis der Regeneration der Extremitäten bei den Arthropoden. Arch. für } \\
\text { Entwicklungsmechanik der Org. 22, 289-324 (1906). } \\
\text { 18. Penzlin, H. Die Bedeutung des Nervensystems für die Regeneration bei den Insekten. Wilhelm Roux. } \\
\text { Arch. Entwickl. Mech. Org. 155, 152-161 (1964). } \\
\text { 19. Urvoy, J. Influence of inversion of the "nerves" of the metathoracic paws on the gait of Blabera } \\
\text { craniifer Burm. Bull. Biol. Fr. Belg. 100, 367-77 (1966). }\end{array}$ \\
\hline Platyhelminthes & $\begin{array}{l}27,31,32,60 \\
75,79,85,87\end{array}$ & 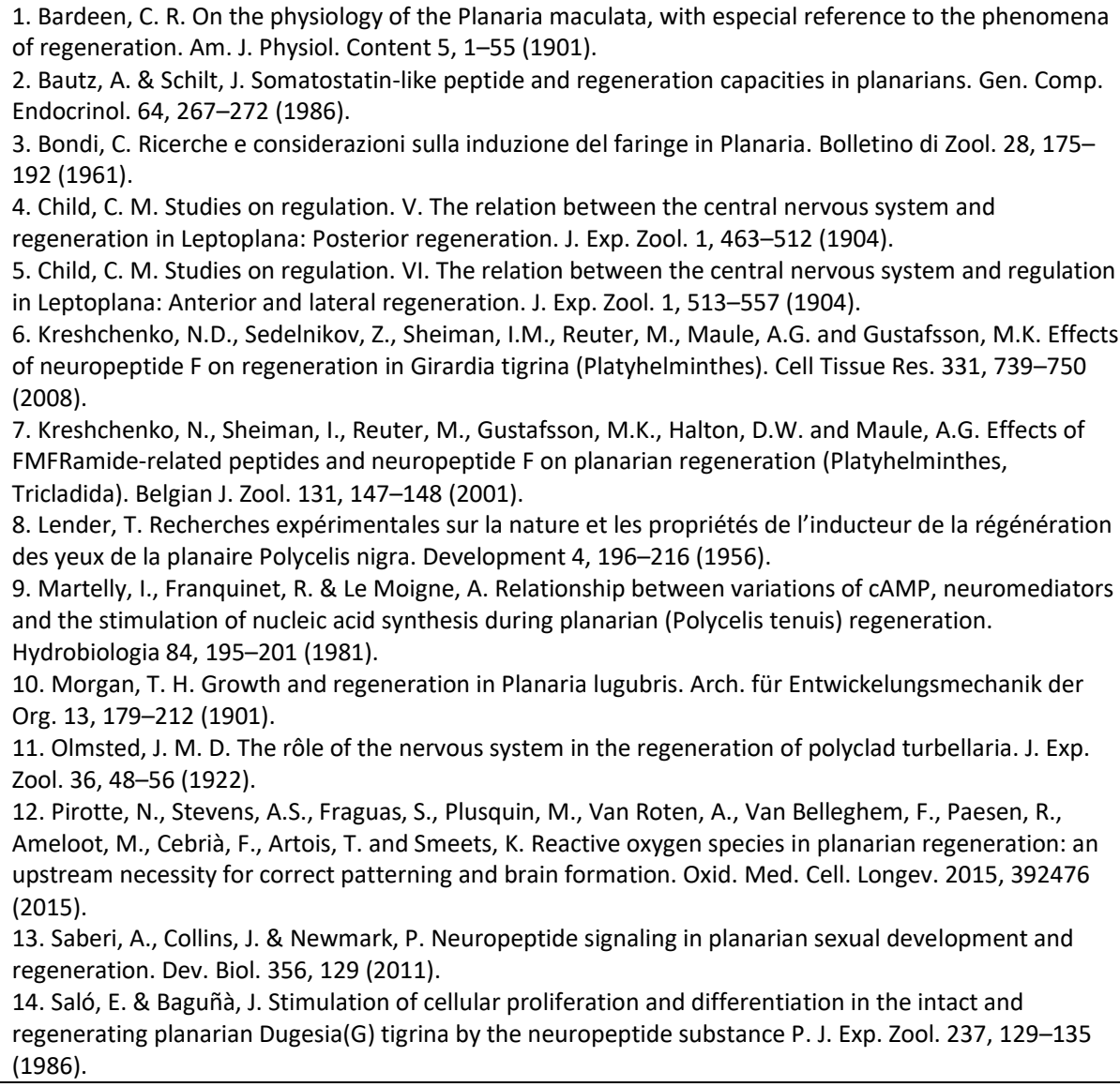 \\
\hline Mollusca & $40,93,94$ & $\begin{array}{l}\text { 1. Andrews, P. L. R., Ponte, G., Fiorito, G., Shaw, T. J. \& Osborne, M. Mechanisms of wound closure } \\
\text { following acute arm injury in Octopus vulgaris. Zool. Lett. 2, 3-5 (2016). } \\
\text { 2. Eakin, R. M. \& Ferlatte, M. M. Studies on eye regeneration in a snail, Helix aspersa. J. Exp. Zool. 184, } \\
81-95 \text { (1973). } \\
\text { 3. Feral, J.-P. La régénération des bras de la seiche Sepia officinalis L. (Cephalopoda, Sepioidea) I. Etude } \\
\text { morphologique. Cah. Biol. Mar. 19, 355-361 (1978). } \\
\text { 4. Lange, M. M. On the regeneration and finer structure of the arms of the cephalopods. J. Exp. Zool. 31, } \\
\text { 1-57 (1920). }\end{array}$ \\
\hline Annelida & $\begin{array}{l}14,16,21,25 \\
34,55,62,69 \\
80\end{array}$ & $\begin{array}{l}\text { 1. Bailey, P. L. \& Bailey, G. H. Further experiments on the influence of the nerve cord in posterior } \\
\text { regeneration in Eisenia and Nereis. J. Exp. Zool. 79, 13-33 (1938). } \\
\text { 2. Bailey, P. L. Anterior regeneration in the earthworm, Eisenia, in the certain absence of central nervous }\end{array}$ \\
\hline
\end{tabular}




\begin{tabular}{|c|c|c|}
\hline & & 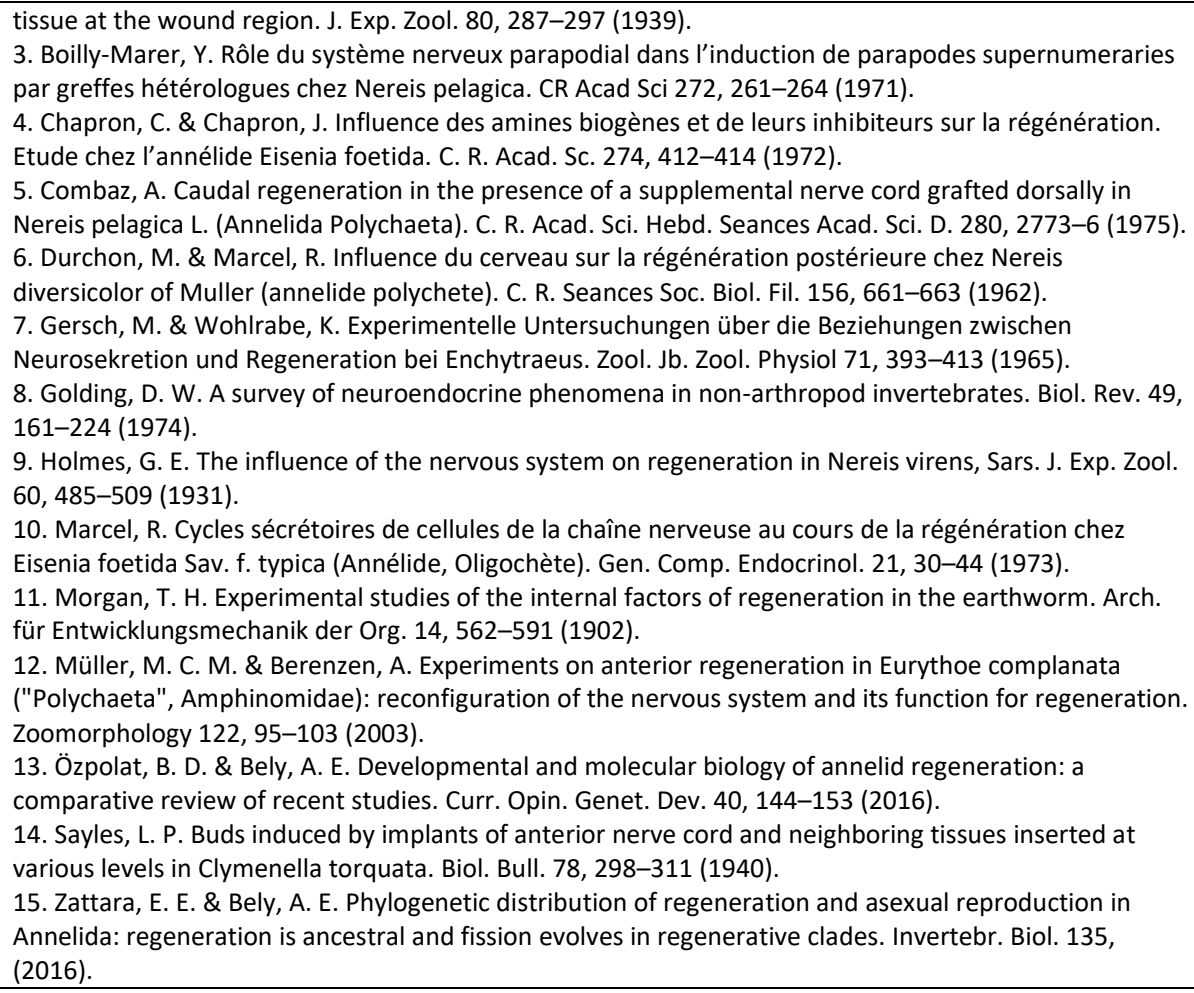 \\
\hline Sipuncula & 15 & $\begin{array}{l}\text { 1. Schleip, W. Die Regenerationsstrang bei Phascolosoma minutum (Kef.) (Sipunculidae). Zeitschrift für } \\
\text { wissenschaftliche Zool. 146, 104-122 (1934). } \\
\text { 2. Wegener, F. Beitrag zur Kenntnis der Russelregeneration der Sipunculiden. Zeitschrift für } \\
\text { wissenschaftliche Zool. 150, 527-565 (1938). }\end{array}$ \\
\hline Nemertea & 22 & $\begin{array}{l}\text { 1. Coe, W. R. Regeneration in nemerteans. J. Exp. Zool. 54, 411-459 (1929). } \\
\text { 2. Coe, W. R. Regeneration in nemerteans. III. Regeneration in Lineus pictifrons. J. Exp. Zool. 61, 29-43 } \\
\text { (1932). }\end{array}$ \\
\hline Phoronida & 43 & \\
\hline Echinodermata & $\begin{array}{l}13,20,23,24 \\
35,41,49,76 \\
78\end{array}$ & $\begin{array}{l}\text { 1. Candia Carnevali, M. D. \& Bonasoro, F. Microscopic overview of crinoid regeneration. Microsc. Res. } \\
\text { Tech. 55, 403-426 (2001). } \\
\text { 2. Carnevali, M.D.C., Bonasoro, F., Invernizzi, R., Lucca, E., Welsch, U. and Thorndyke, M.C. Tissue } \\
\text { distribution of monoamine neurotransmitters in normal and regenerating arms of the feather star } \\
\text { Antedon mediterranea. Cell Tissue Res. 285, 341-352 (1996). } \\
\text { 3. Di Benedetto, C., Parma, L., Barbaglio, A., Sugni, M., Bonasoro, F. and Carnevali, M.D.C. Echinoderm } \\
\text { regeneration: an in vitro approach using the crinoid Antedon mediterranea. Cell Tissue Res. 358, (2014). } \\
\text { 4. Elphick, M. R., Emson, R. H. \& Thorndyke, M. C. FMRFamide-like immunoreactivity in the nervous } \\
\text { system of the starfish Asterias rubens. Biol. Bull. 177, 141-145 (1989). } \\
\text { 5. Franco, C. F., Soares, R., Pires, E., Santos, R. \& Coelho, A. V. Radial nerve cord protein phosphorylation } \\
\text { dynamics during starfish arm tip wound healing events. Electrophoresis 33, 3764-3778 (2012). } \\
\text { 6. Huet, M. Le rôle du système nerveux au cours de la régénération du bras chez une étoile de mer : } \\
\text { Asterina gibbosa penn. (echinoderme, asteride). J. Embryol. Exp. Morph. 33, 535-552 (1975). } \\
\text { 7. Huet, M. Role of oral nervous annuli in regeneration of Asterina gibbosa (Echinoderma, Asterida). Bull. } \\
\text { LA Soc. Zool. Fr. Zool. 103, 414-415 (1978). } \\
\text { 8. Mashanov, V. S., Zueva, O. R. \& García-Arrarás, J. E. Transcriptomic changes during regeneration of the } \\
\text { central nervous system in an echinoderm. BMC Genomics } 15,357 \text { (2014). } \\
\text { 9. Moss, C., Hunter, A. J. \& Thorndyke, M. C. Patterns of bromodeoxyuridine incorporation and } \\
\text { neuropeptide immunoreactivity during arm regeneration in the starfish Asterias rubens. Philos. Trans. } \\
\text { Biol. Sci. 353, 421-436 (1998). } \\
\text { 10. Morgulis, S. Regeneration in the brittle-star Ophiocoma pumila, with reference to the influence of } \\
\text { the nervous system. Proc. Am. Acad. Arts Sci. } 44,655 \text { (1909). } \\
\text { 11. Smith, G. N. Regeneration in the sea cucumber Leptosynapta. II. The regenerative capacity. J. Exp. } \\
\text { Zool. 177, 331-342 (1971). }\end{array}$ \\
\hline Hemichordata & 54 & \\
\hline Cephalochordata & 95 & \\
\hline Urochordata & & $\begin{array}{l}\text { 1. Bollner, T., Beesley, P. W. \& Thorndyke, M. C. Pattern of substance P- and cholecystokinin-like } \\
\text { immunoreactivity during regeneration of the neural complex in the ascidian Ciona intestinalis. J. Comp. } \\
\text { Neurol. 325, 572-580 (1992). } \\
\text { 2. Sutton, M. F. The regeneration of the siphons of Ciona intestinalis L. J. Mar. Biol. Assoc. United } \\
\text { Kingdom 32, } 249 \text { (1953). }\end{array}$ \\
\hline
\end{tabular}




\begin{tabular}{|c|c|c|}
\hline Vertebrata & $\begin{array}{l}1,5,6,8-12 \\
17-19,26,28- \\
30,33,36-38 \\
44-47,51-53 \\
59,63-65,67 \\
70-71,73,81 \\
86,91\end{array}$ & 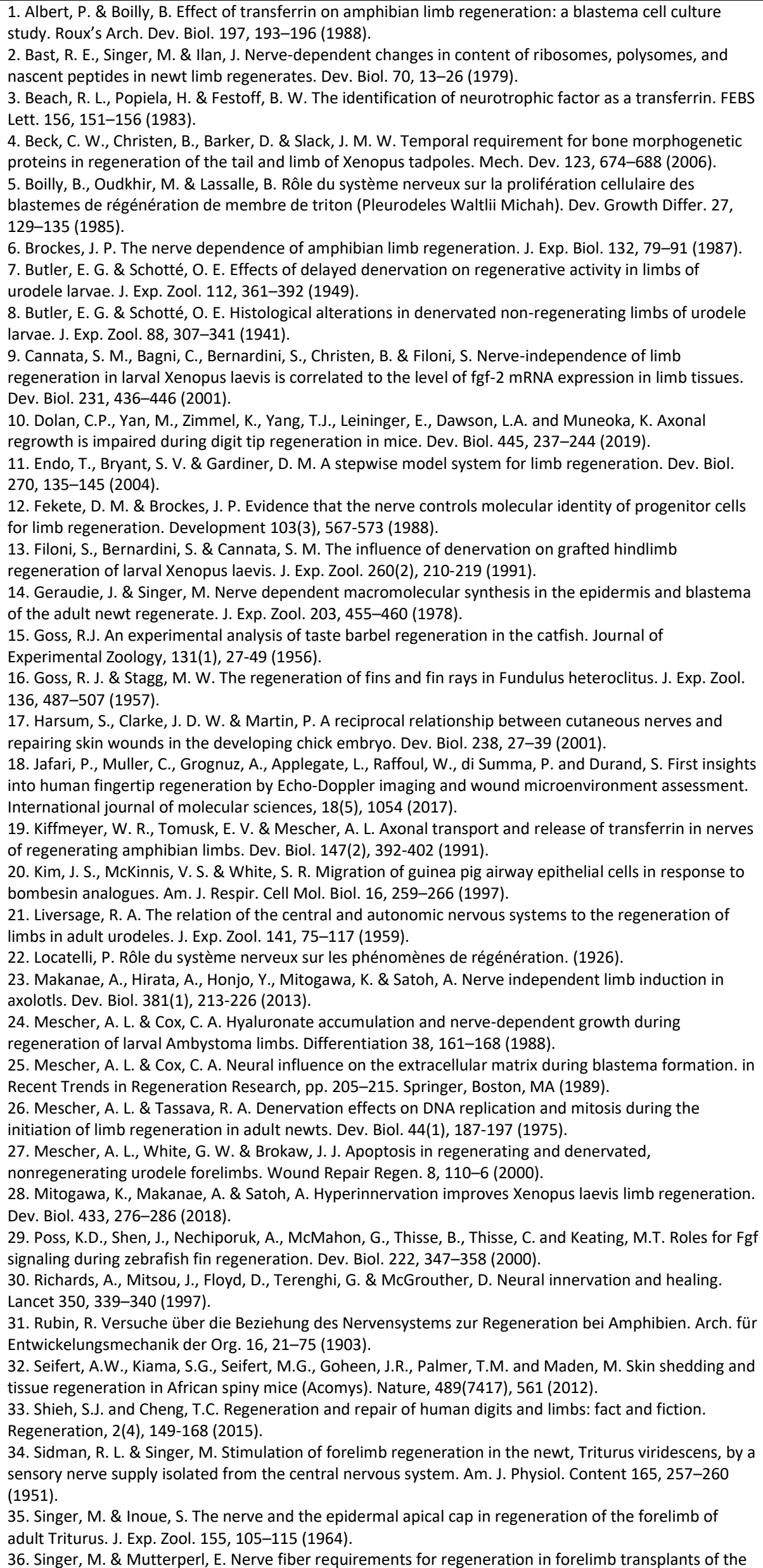 \\
\hline
\end{tabular}




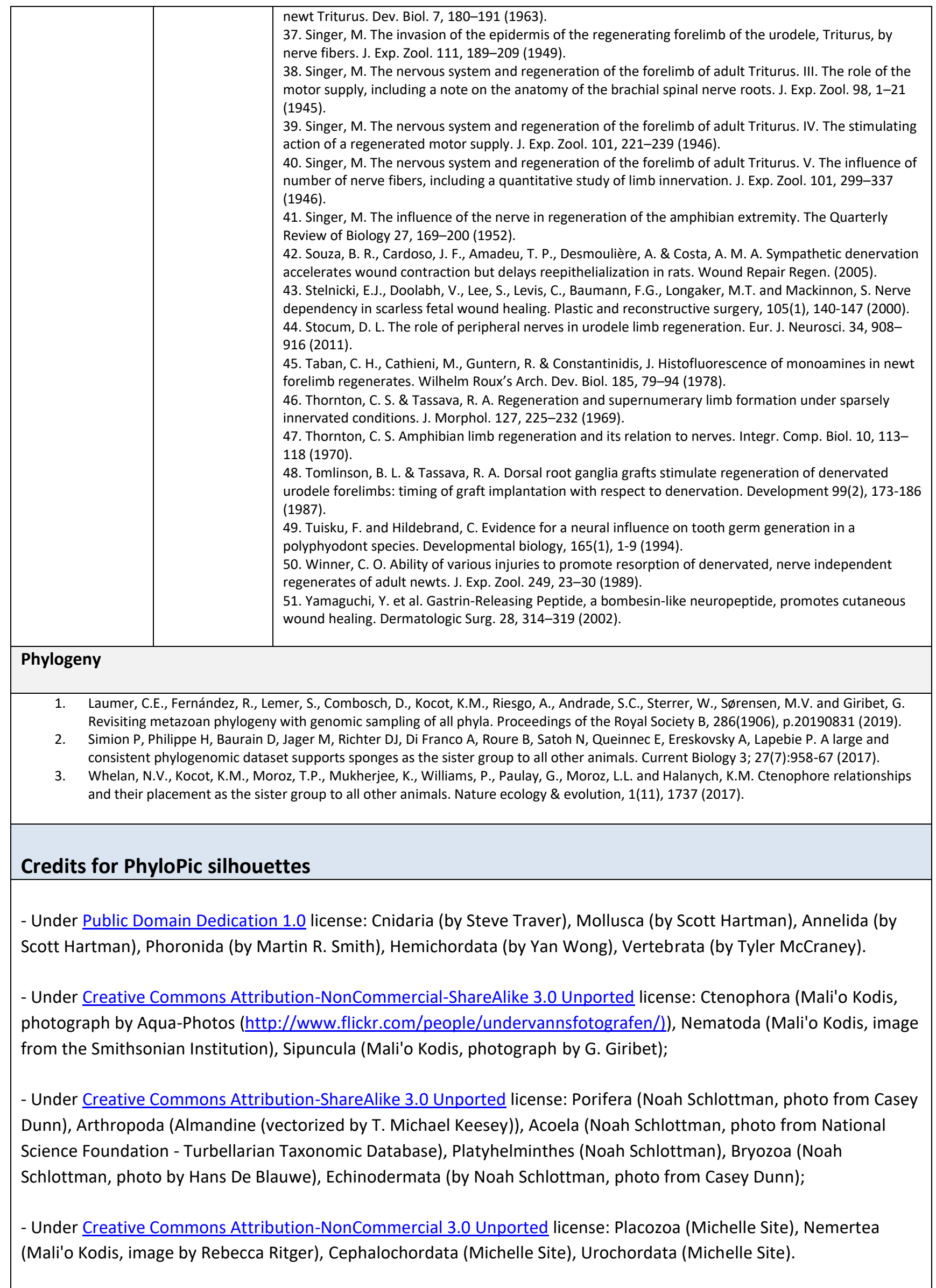

